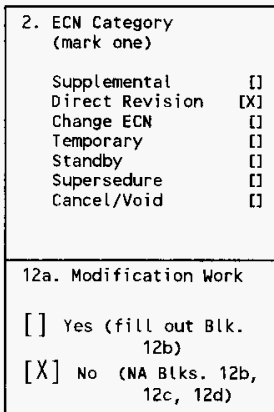

13a. Description of Change

Full scale revision
3. Originator's Name, Organization, MSIN, and Telephone No.

K. E. Smith, SNF Project, R3-86, 376-0273

6. Project Title/No./Work Order No.

Multi-Canister Overpack/W-442

9. Document Numbers changed by this ECN (includes sheet no. and rev.) WHC-SD-SNF-SOW-001, Rev. 1 12b. Work Package No.

NA 12c. Modification Work Complete
N/A
Design Authority/Cog. Engineer
Signature \& Date

13b. Design Basel ine Document?

e

Page 1 of 2 ECN

Full scale revision

13b. Design Basel ine Document?

\title{
(n)
}

5. Date 


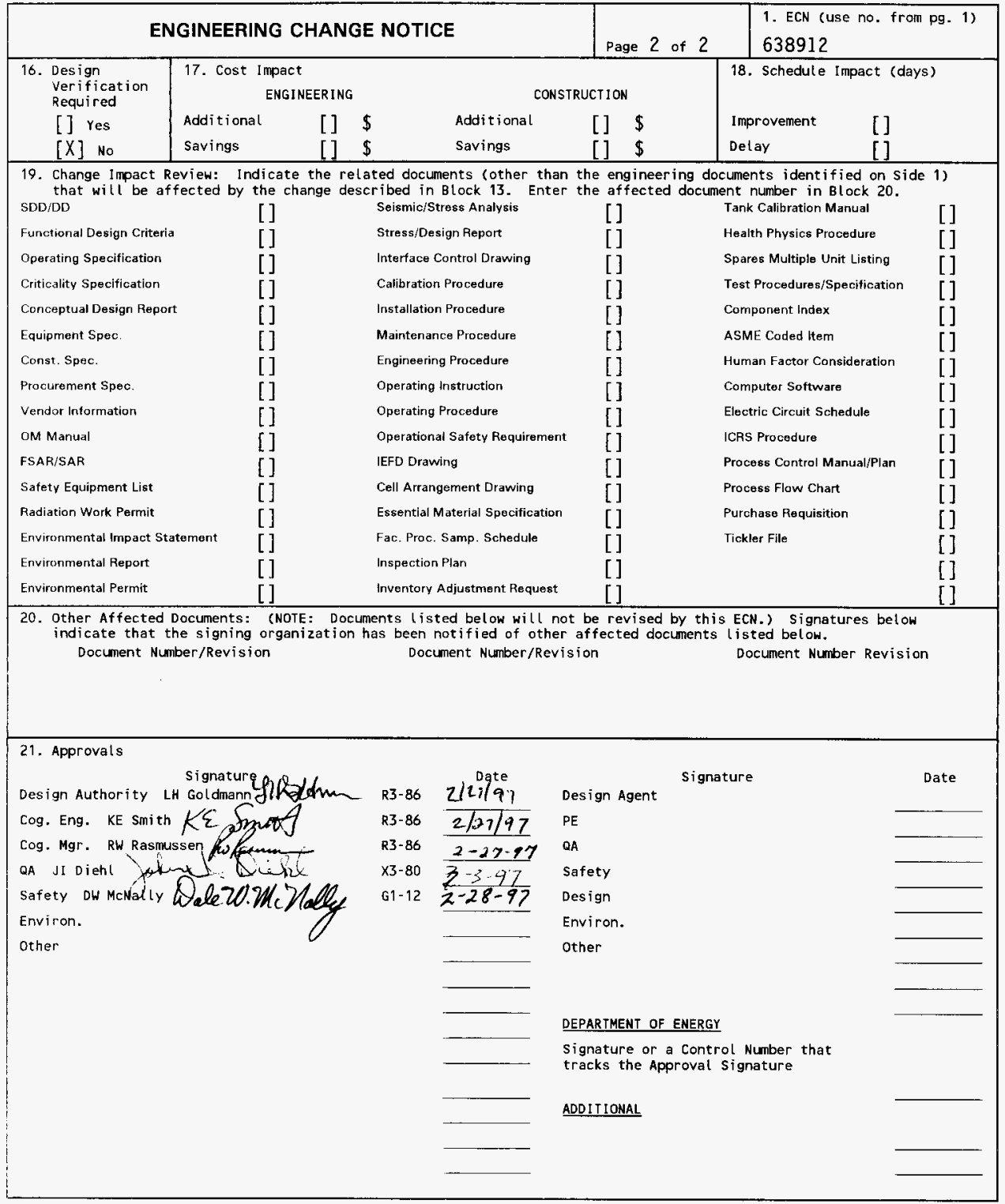




\section{Statement of Work for System Design and Engineering of the Spent Nuclear Fuel Multi- Canister Overpack}

\section{K. E. Smith}

DE\&S Hanford, Inc., Richland, WA 99352

U.S. Department of Energy Contract DE-AC06-96RL13200

$\begin{array}{lll}\text { EDT/ECN: } & 638912 & \text { UC: UC-510 } \\ \text { Org Code: } & 2 T 400 & \text { Charge Code: LE008 } \\ \text { B\&R Code: } & \text { EW7040000 } & \text { Total Pages: } 2 Z \text { 22 kne } 3 / 1,7\end{array}$

Key Words: Spent Nuclear Fue $\}$, Multi-Canister Overpack, Packaging

Abstract: This document describes the workscope for final design of the Multi-Canister Overpack to be used for long-term storage of $\mathrm{N}$ Reactor fuel.

AutoCAD is a Registered Trademark of AutoDesk, Inc.

TRADEMARK DISCLAIMER. Reference herein to any specific commercial product, process, or service by trade name, trademark, manufacturer, or otherwise, does not necessarily constitute or imply its endorsement, recommendation, or favoring by the United States Government or any agency thereof or its contractors or subcontractors.

Printed in the United States of America. To obtain copies of this document, contact: Document Control Services, P.0. Box 950, Mailstop H6-D8, Richland WA 99352, Phone (509) 372-2420:

Fax (509) 376-4989.
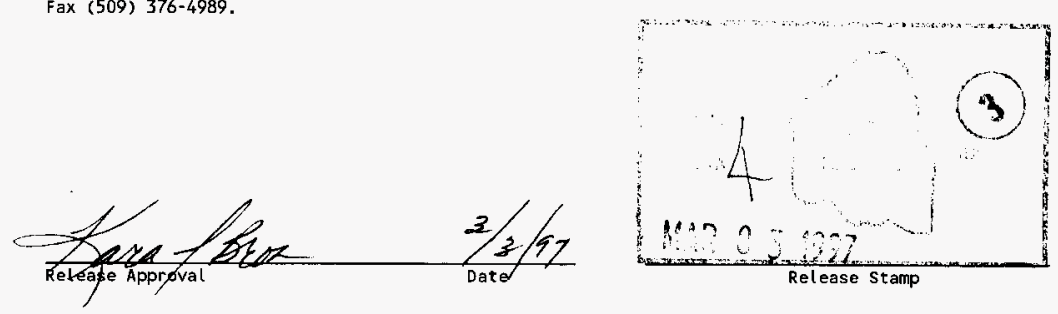

\section{Approved for Public Release}


(2) Title

Statement of Work for System Design and Engineering of the Spent Nuclear Fuel MultiCanister Overpack

CHANGE CONTROL RECORD

\begin{tabular}{|l|l|} 
(3) Revision & (4) Description of Change - Replace, Add, and Delete Pages \\
\hline 0 & (7) EDT-613009 \\
\hline 1 & Fully revised per ECN 634996 \\
\hline 2 RS & Fully revised per ECN 638912 \\
\hline
\end{tabular}

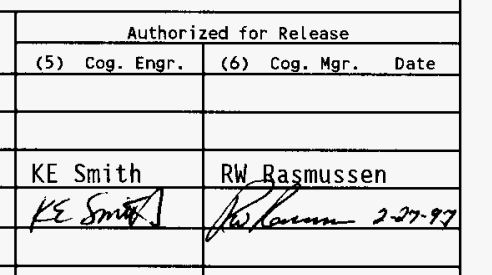


HNF-SD-SNF-SOW-001

Rev. 2

\title{
STATEMENT OF WORK FOR SYSTEM DESIGN AND ENGINEERING OF THE SPENT NUCLEAR FUEL MULTI-CANISTER OVERPACK
}

\author{
HNF-SD-SNF-SOW-001 \\ Revision 2
}

FEBRUARY 1997

Prepared for the U.S. Department of Energy

Office of Environmental Restoration and Waste Management 


\section{TABLE OF CONTENTS}

1.0 INTRODUCTION . . . . . . . . . . . . . . . . . . . . . . 1

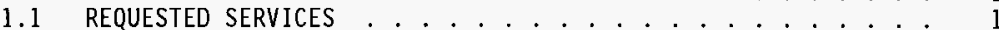

1.2 BACKGROUND . . . . . . . . . . . . . . . . 1

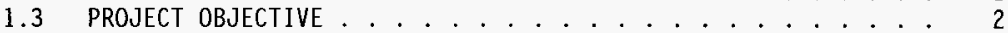

2.0 WORK SCOPE . . . . . . . . . . . . . . . . . . . . 2

2.1 GENERAL . . . . . . . . . . . . . . . . . . 3

2.2 DESIGN RESPONSIBILITY . . . . . . . . . . . . . . . . . . . . 3

2.3 DESIGN REQUIREMENTS . . . . . . . . . . . . . . . . . 3

2.4 SCHEDULE . . . . . . . . . . . . . . . . . . 3

2.5 PRELIMINARY INFORMATION . . . . . . . . . . . . . . 4

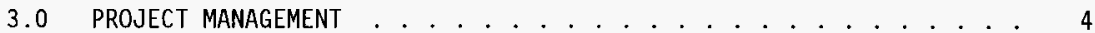

3.1 MANAGEMENT APPROACH . . . . . . . . . . 4

3.2 TECHNICAL DIRECTION . . . . . . . . . . . . . . . . . . . . 4

3.3 BUSINESS MANAGEMENT . . . . . . . . . . . . . . . . . . . . 5

3.3.1 Issues/Concerns and Action Tracking System . . . . . 5

3.3.2 Monthly Reports . . . . . . . . . . . . . . 5

3.4 MEETINGS AND REVIEWS . . . . . . . . . . . . . . 6

3.4.1 Kick-0ff Meeting . . . . . . . . . . . . . . . 6

3.4 .2 Status Meetings . . . . . . . . . . . . . . . . . . 6

3.4.3 Design Reviews . . . . . . . . . . . . . . . . . . 6

3.4.4 Coordination Meetings . . . . . . . . . . . . 6

3.5 DOCUMENT REQUIREMENTS ................... . . . 6

3.5.1 General Data ................ . . 7

3.5.2 Document Control . . . . . . . . . . . . . . . . 7

3.5.3 Document Identification and Format . . . . . . . . . 7

3.5.4 Document Approva1 . . . . . . . . . . . . . . . 8

3.5 .5 Document Transmittal . . . . . . . . . . . . . 8

3.6 RECORDS MANAGEMENT PROCEDURES . . . . . . . . . . . . . . . . . . . . 9

3.6.1 Record Files and Objective Evidence . . . . . . . . . 9

3.7 CONF IGURATION MANAGEMENT . . . . . . . . . . . . . . . . . 9

3.8 QUALITY ASSURANCE . . . . . . . . . . . . . . . . . . . 9

3.8.1 Qual ity Assurance Plan (QAP) . . . . . . . . . . . . . 9

3.8.2 Quality Assurance Accessibility . . . . . . . . . . . 10

3.8.3 Corrective Action . . . . . . . . . . . . . . . . 10

3.8.4 Qual ity Assurance Matrix . . . . . . . . . . . . . . 10

3.8.5 Quality Assurance Reporting . . . . . . . . . . . 10

3.9 INDEPENDENT SAFETY PROGRAM .................. . . . 10

3.10 CHANGE CONTROL . . . . . . . . . . . . . . . . . . . . 11

4.0 DESCRIPTION OF REQUIRED SERVICES . . . . . . . . . . . . . . 11

4.1 Phase 2 Design Objectives.................. . . . . 11

4.2 DESIGN WORK ITEMS ....................... . . . . . . . 11

4.2.1 Design End Items................... 14

5.0 REFERENCES ......................... . . . . 15

6.0 BIBLIOGRAPHY . . . . . . . . . . . . . . . . . . . . 16

7.0 ACRONYMS . . . . . . . . . . . . . . . . . 17 
HNF-SD-SNF-SOW-001

Rev. 2

\section{LIST OF TABLES}

Table 1-1 MCO Subproject Milestones ... . . . . . . . . . . . . . 2

Table 2-1 Milestone Schedule . . . . . . . . . . . . . . . . 4

Table 4-1 Design End Items ....................... 14 


\section{STATEMENT OF WORK FOR PHASE 2 \\ DESIGN OF THE MULTIPLE CANISTER OVERPACK SUBPROJECT}

\subsection{INTRODUCTION}

\subsection{REQUESTED SERVICES}

This Statement of Work (SOW) describes the work scope for the preparation of the Phase 2 (final) design for the Multiple Canister Overpack (MCO) equipment. The MCO is to be used as the radiological containment device for the Spent Nuclear Fuel (SNF) assemblies, currently in wet storage in $K$ East and West Basins, to be transported and stored in the Canister Storage Building (CSB) until final disposal facilities are made available. The engineering services contractor will be requested to provide reports, studies, analyses, engineering, drawings, specifications, estimates and schedules.

The overall goal of this task order is to do the following:

1. Prepare a fabrication specification, ASME Code exception report, a packaging, shipping and warehouse plan, and detailed fabrication drawings of the MCO in accordance with the MCO Performance Specification (HNF-S-0426, Rev. 3) for procurement activities by the SNF MCO Subproject.

2. Establish and maintain a comment data base on the comments, resolutions, changes to the design of the MCO.

3. Support fabrication activities through the review of vendor fabrication drawings and shop test reports.

\subsection{BACKGROUND}

The Hanford Spent Nuclear Fuel Project has committed to an accelerated schedule for removing spent nuclear fuel from the $K$ Basins to a new storage facility in the 200 Areas. A key part of this action involves retrieval of the SNF materials from the basin water storage pools and transfer into the MCOs that will be used for storage of fuel prior to and after conditioning. The MCO is one of the most critical components of the overall system because of its multiple functions and interfaces. The Mco interfaces with several portions of the SNF Project during its life cycle.

The general MCO interfaces are 1 isted below:

- The MCO is used in the basin as a container for the SNF being removed from the $K$ West and East Basins. The fue 1 is to be reracked into a fuel basket and the basket is then loaded into the MCO in the basin pool. After sealing, the MCO is then drained of free water and vacuum dried at the Cold Vacuum Drying (CVD)

Facility before being stored at the CSB. 
HNF-SD-SNF-SOW-001

Rev. 2

- The MCO is used in conjunction with the shipping cask to contain and transport the SNF to the CSB.

- The MCO is used at the Hot Conditioning System (HCS) Facility as a conditioning vessel whereby some of the hydrates and hydrides on the SNF and in the MCO are broken down to release some of their compounded hydrogen.

- The MCO is used at the CSB to hold and contain the SNF during an interim storage period of up to 75 years. The CSB location is within the 200 East Area of the Hanford Site, approximately $48 \mathrm{~km}$ (30 mi) northwest of Richland, Washington.

\subsection{PROJECT OBJECTIVE}

The SNF MCO Subproject objective is to design, fabricate, test, and procure the containment vessel and internal components for the fuel assemblies to support initiation of fuel removal activities by December 1997 .

The high level subproject milestones are depicted in Table 1-1.

Table 1-1 MCO Subproject Milestones

\begin{tabular}{|l|l|c|}
\hline $\begin{array}{c}\text { Milestone } \\
\text { Number }\end{array}$ & \multicolumn{1}{|c|}{ Title } & Date \\
\hline & Begin Phase 2 (final) design. & $10 / 01 / 96$ \\
\hline & Phase 2 design 100\% complete & $04 / 18 / 97$ \\
\hline & Award Fabrication Contract & $05 / 01 / 97$ \\
\hline & Deliver first shipment of MCOs & $03 / 02 / 98$ \\
\hline & Begin Initial shipment of Fuel & $05 / 31 / 98$ \\
\hline
\end{tabular}

\subsection{WORK SCOPE}

This SOW is intended to address the Phase 2 design through April 1997. Support during latter phases of this project may be administered through revisions to this SOW. The Seller shall be fully responsible and accountable for the work performed under this SOW. The Seller shall be responsible and accountable for the professional quality, technical accuracy, costeffectiveness, timeliness, coordination, and development of all end item deliverables performed under this SOW. All technical work shall comply with the MCO Performance Specification (HNF-S-0426, Rev. 3). 
HNF-SD-SNF-SOW-001

Rev. 2

\subsection{GENERAL}

The Seller shall perform Phase 2 design in sufficient detail to permit procurement of MCOs under a firm fixed price contract.

In addition to all basic design support analyses (such as structural, seismic, thermal, etc.), the Seller shall also perform all required special design support analyses, including, but not limited to, shielding; reliability, availability, and maintainability; life-cycle cost; human factors engineering assessment; operability/maintainability assessments; etc. The final design work sha11 be documented and summarized in a Design Report. A11 design media prepared under this contract sha11 become the property of the DOE.

The Phase 2 design shall incorporate the design features resulting from the prototype development and testing program. Prototype fabrication drawings and analyses will be provided to the Seller for incorporation into Phase 2 design. The Seller should notify the Technical Representative (MCO Subproject Design Authority) of any deviations from these design features deemed necessary to comply with the Performance Specification, and include justification for the change. The Seller shall obtain Technical Representative concurrence for each deviation.

\subsection{DESIGN RESPONSIBILITY}

The Seller shall be considered the responsible design agent ensuring that the overall MCO design, including designs furnished by subcontractors, meets all the specification criteria.

\subsection{DESIGN REQUIREMENTS}

The design sha11 be in accordance with the MCO Performance Specification (HNF-S-0426, Rev. 3).

\subsection{SCHEDULE}

The MCO Phase 2 Design milestones are presented in Table 2-1. The Seller should propose in work plan a schedule for the deliverables to be provided at the $60 \%$ and $90 \%$ design reviews.

Deliverables at the $90 \%$ complete milestone should be fully developed, except for incorporating reviewer comments, which represents the final $10 \%$ of the design effort. 
HNF-SD-SNF-SOW-001

Rev. 2

Table 2-1 Milestone Schedule

\begin{tabular}{|l|c|}
\hline \multicolumn{1}{|c|}{ Milestone* } & Date \\
\hline Phase 2 Design Task Award & $10 / 04 / 96$ \\
\hline Phase 2 Design 60\% review completed & $12 / 23 / 96$ \\
\hline Phase 2 Design 90\% review initiated & $03 / 05 / 97$ \\
\hline Phase 2 Design 100\% complete & \\
\hline
\end{tabular}

"Completion of schedule milestones shall be defined as receipt of required documents.

\subsection{PRELIMINARY INFORMATION}

A11 prototypic design media (drawings, analyses, studies, etc.) will be provided under separate cover.

\subsection{PROJECT MANAGEMENT}

This section describes the project management approach and the requirements for the Seller project management system for the MCO Subproject Design phase.

\subsection{MANAGEMENT APPROACH}

Overall project management will be provided by the SNF MCO Subproject Manager. Administration of the Seller contract will be provided by the designated procurement specialist. The SNF MCO Design Authority is the Technical Representative for all scope included in this Statement of Work.

\subsection{TECHNICAL DIRECTION}

The SNF MCO Technical Representative has the responsibility and authority to provide technical direction to the Seller for activities within the scope of this SOW. Any changes to the requirements of this SOW, or direction that impacts any of the contract cost/schedule provisions or its terms or conditions, must come only from the procurement specialist. The Seller shall notify the procurement specialist of any direction it has received from the SNF MCO Technical Representative or Subproject Manager that impacts the contract provisions and request authorization. 
HNF-SD-SNF-SOW-001

Rev. 2

\subsection{BUSINESS MANAGEMENT}

\subsubsection{Issues/Concerns and Action Tracking System}

The Seller shall develop and maintain an issues and concerns tracking system. This system shall record and track significant design-related issues that are raised by any SNF subproject participant or outside oversight entity, but are not immediately resolvable. The system shall clearly identify the issue, the party responsible for resolution, and a planned issue closure date. The system shall include issues/actions raised via correspondence and during meetings.

In addition the Seller will establish and maintain a comment database containing the questions, comments, concerns and the resolution of the issues, actions and concerns.

\subsubsection{Monthly Reports}

The Seller shall provide monthly status reports. These reports shall be submitted on or before the tenth day of each month (for the previous month) and shall include, but not be limited to, the following information:

- Project manager's narrative highlights and status assessment for each CWBS element including activities planned for the next month

- Issues/concerns (cost, schedule, technical), recommended solution, and progress toward resolution

- DOE "Cost Performance Report" formats 1 and 3 and Variance Analysis (see DOE Order 1332.1A, Uniform Reporting System [DOE 1985]) completed at the CWBS level. The monthly Cost Performance Reports should provide integrated CWBS cost/schedule data for measuring performance. Earned value progress and any changes in the latest revised estimate shall be included in the cost

Performance Report. The Variance Analysis shall be on the current month and cumulative-to-date and include cause, effect, and corrective action. The variance analysis shall be prepared at the CWBS level with explanation lower required to adequately address problems (offsetting variance, etc.). Cost and schedule variance analysis thresholds (current month and cumulative date) shall be $\$ 10 \mathrm{k}$ and $10 \%$.

- Statused critical path logic network schedules and a forecast of schedule impacts, including a statused log of control milestones. 
HNF-SD-SNF-SOW-001

Rev. 2

\subsection{MEETINGS AND REVIEWS}

\subsubsection{Kick-0ff Meeting}

A design kick-off meeting will be held at the Seller's office after the task is awarded. The purpose of the meeting is to provide the Seller with approved documents to accomplish the required activities. This meeting will focus on a discussion of the SOW and Seller's work plan.

\subsubsection{Status Meetings}

$\mathrm{Bi}$-weekly meetings shall be held at the Seller's offices to review progress of the work. During these meetings, the Seller shall present subproject technical progress. During the presentation, the Seller shall identify existing or anticipated problem areas for each activity (including impacts), and report on progress toward problem resolution. The Seller shall prepare and distribute the meeting minutes within 10 working days after the meeting for approval by the SNF MCO Subproject Manager. Minutes shall emphasize issues, concerns and planned actions.

\subsubsection{Design Reviews}

Design review meetings shall be held to ensure that the design objectives are being achieved. A formal review will be conducted at the $90 \%$ complete milestone. The Seller should allow for a ten working day review by the Buyer's design review team, after which comments will be forwarded to the Seller for disposition, incorporation, and tracking. If necessary, meetings shall be held to ensure that the design objectives are being achieved and to resolve significant comments in a timely manner to allow for the completion of the design task. The $60 \%$ and $90 \%$ Design reviews shall be identified in the work plan.

\subsubsection{Coordination Meetings}

Coordination meetings, including telephone conferences, will be held as required, between the Technical Representative and the Seller to discuss various subproject issues as they arise. Meeting minutes will be prepared by the Seller and issued to the meeting participants within 5 working days of the meeting for review and comments. Any oral communications (including telephone conferences) having an impact on the work shall be issued with a controlled record number and maintained as subproject records.

\subsection{DOCUMENT REQUIREMENTS}

Record documents and contract documents will be generated during the course of the design. Record documents are those end-item documents required by this SOW. Contract documents are those documents identified in the task order agreement and this sow. 
HNF-SD-SNF-SOW-001

Rev. 2

\subsubsection{General Data}

A11 drawings from detailed design shall be prepared using the computeraided design and drafting (CADD) process compatible with the AutoCAD.dwg drawing format. Any exceptions shall be identified and submitted for approval. It is the intent of the Project to produce all final engineering drawings in compliance with the requirements defined in ICF KH Hanford A/E Standard, General Manual GG-DWG-01. During the Design phase, the Seller shall implement cost-effective compliance to the requirements of GG-DWG-01. If Seller proprietary software is used, the Buyer shall have free access to it after the design is completed. All commercial software user rights will be transferred to the Buyer on or before the project is completed.

Full-size drawings shall be 71 by $102 \mathrm{~cm}$ (28 by 40 in.). Reduced drawings can be 36 by $50 \mathrm{~cm}$ ( 14 by $20 \mathrm{in.)}$ if mutually agreed upon by the Technica? Representative and the Seller. Drawings or sketches included in topical reports can be 28 by $43 \mathrm{~cm}$ (11 by 17 in.). Drawing sizes other than those listed may be accepted on a mutually agreed upon basis. Reproducibles for drawings shall be furnished by the Seller pending approval by the Technical Representative.

\subsubsection{Document Control}

Preparation, identification, approval, transmittal, and final disposition of new and revised record documents shall conform to the Seller's established procedures or special instructions. Use of contract documents shall be controlled in accordance with the Seller's established procedures or special instructions. The Seller shall identify in their work plan the document control procedures intended for use.

\subsubsection{Document Identification and Format}

The Seller is required to use a numbering system for all documents, including correspondence, technical reports, drawings and specifications, etc. The numbering system will be developed by the Seller and concurred with by the Technical Representative. Numbering sequences for sketches and drawings shall be provided by the Technical Representative.

Each record document shall have the following format:

- Project and contract identification

$$
\begin{array}{ll}
\text { - } & \text { SNF } \\
\text { - } & \text { Project number, if assigned } \\
\text { - } \quad \text { Contract number }
\end{array}
$$

- Originating firm's name

- Document title

- Document identification number (on each page) 
- Revision or addendum number or letter (on each page with revised portion of page indicated)

- Issue or revision date (released documents only)

- Authorized use stamp (e.g., draft, for approval, approved for construction, proprietary information, secret)

- Total number of pages and number of each page (e.g., page 1 of 4)

- Table of contents or attachments (as needed)

- Approval signature and title of responsible person in originating firm (released documents only).

\subsubsection{Document Approval}

Al1 design drawings and technical documents submitted for review shall first be appropriately reviewed by the Seller's responsible technical staff including, but not limited to, QA, safety, and drafting checker personnel. Reports and documents shall be checked for technical and editorial accuracy before they are submitted for any review. Final design drawings, reports, and documents submitted for acceptance shall be approved by the Seller. The Seller shall have written procedures in place that delineate the requirements for reviewing, checking, technical editing, and approval of documents before issuance. These procedures shall be issued for review and concurrence with the document control plan.

Acceptance by the Technical Representative is the act of reviewing an activity or document and acknowledging that it may be used for the purpose intended at that time. Acceptance by the Technical Representative does not ensure that future changes will not be required, and does not convey or imply approval, or assumption of responsibility for the activity or document. The originator remains fully responsible for all aspects of the activity or document; for fulfilling all specifications; and for any other obligation or liability otherwise arising under a specification, agreement, or contract.

\subsubsection{Document Transmittal}

Unless otherwise agreed upon, transmittal of record documents shall include one reproducible and 10 copies. For documents larger than 21.6 by $27.9 \mathrm{~cm}$ ( $81 / 2$ by 11 in.), full-size, photo-quality reproducibles shall be included. Transmittal of record documents produced electronically shall include indices that identify directory and data set file names. Transmittals shall be documented on a suitable, sequentially numbered form that contains a standard document identification number, distribution, and space for reviewers to note the disposition of listed attachments in accordance with DOE Order 1324.2A, Records Disposition (D0E 1988b) and the Seller Project document transmittal procedure. All final deliverables shall also be provided on an electronic file (e.g., CADD, ANSYS, WP5.1, etc.). 
HNF-SD-SNF-SOW-001

Rev. 2

\subsection{RECORDS MANAGEMENT PROCEDURES}

Records shall be managed in accordance with the procedures submitted in the Seller's work plan. Records management shall include receipt, transmittal, processing, disposition, and storage requirements.

\subsubsection{Record Files and Objective Evidence}

Record files with current and previous revisions shall be maintained for record documents in accordance with the Seller's approved QA plan. At the conclusion of the design and fabrication phase, the Seller witl be advised of the files' disposition. The Seller shall keep duplicate copies of data to meet code or legal requirements.

Objective evidence is test material and unreduced data that support record documents. Objective evidence includes, but is not limited to, material samples used in examinations and tests, instrument records, radiographs, and photographs. Unless needed for evaluation of a nonconformance or other special use, objective evidence will not be distributed. A "record only" transmittal should be issued with the objective evidence 1 isted in the document index and retained with the record files.

\subsection{CONFIGURATION MANAGEMENT}

The Seller shall identify the configuration management process for control and status of the Phase 2 Design. This process shall be identified in an update (as-needed) to the CMP that was prepared for Phase 1 Design and shall be submitted for review and approval. The CMP shall be developed in accordance with the guidelines contained in DOE Order 4700.1 and WHC-SD-SNFCM-001.

\subsection{QUALITY ASSURANCE}

All work under this task order shall be performed in accordance with the Seller's ICF KH approved Quality Assurance Plan. The QA Program shall also comply with those sections of 10 CFR 71, subpart $H$, "Quality Assurance," that affect the particular tasks being performed. Initially, the program shall encompass those $Q A$ elements applicable only to design tasks. Other $Q A$ elements applicable to follow-on services, such as fabrication support and inspection, will be added when options for these services are exercised.

\subsubsection{Quality Assurance Plan (QAP)}

The Seller shall submit for approval an update (as-needed) to the project-specific QAP that was prepared for Phase 1 Design which provides a description of the $Q A$ Program and how the QA requirements in Section 3.8 will be applied to the design work. 
HNF-SD-SNF-SOW-001

Rev. 2

\subsubsection{Quality Assurance Accessibility}

The Seller shall provide access to all documents, files, and workstations for purposes of audit or surveillance of ongoing activities by the SNF Project and its designated agents. The Seller shall provide support, as requested, for audits or surveillances conducted by the Buyer, or the Buyer in conjunction with other project participants and specialists.

\subsubsection{Corrective Action}

The Selier shall be responsive to deficiencies identified by the DOE or SNF Project, via $Q A$ reports, corrective action reports, nonconformance reports, audit/surveillance/management assessment reports, stop work orders, or reviews/evaluations. The Seller shall provide input data (i.e., nonconformance report, corrective action report, audit findings, unsatisfactory surveillance) and develop a project quality trend program that identifies conditions adverse to quality.

\subsubsection{Quality Assurance Matrix}

The Seller shall develop a matrix of implementing procedures. This matrix shall be developed to demonstrate that each of the applicable requirements of ANSI/ASME NQA-1-1989 (ANSI/ASME 1989) and 10 CFR 71, subpart $H$, "Quality Assurance," have been addressed in the Seller's QAP and subsequent implementing procedures. This matrix is a controlled document and shall be annually. updated to address requirements that have been changed, added, or deleted. The QA matrix shall be submitted to the Buyer for concurrence with the QAP.

\subsubsection{Quality Assurance Reporting}

The Seller shall provide to the MCO Subproject Manager a monthly QA report. This report shall contain a status of the QA Program and include summaries of deficiencies that require corrective action, updates of corrective actions, audits performed and results, trend information, and key QA personnel changes. This report shall be submitted with the monthly activity report. Trend information will not initially be required to be addressed until the Seller's project quality trend program has had time to fully mature.

\subsection{INDEPENDENT SAFETY PROGRAM}

The Seller shall be responsible for satisfying all safety requirements imposed on the design by the criteria documents. This shall ensure compliance with safety and health protection requirements (i.e., nuclear safety, fire protection, industrial safety and hygiene, health physics, radiation protection engineering, etc.). Features of the MCO which provide fuel containment and criticality control are considered Safety Class items per WHCCM-4-46, Rev. 2. The specific listing of Safety Class and Safety Significant components is included in the MCO Performance Specification. 
HNF-SD-SNF-SOW-001

Rev. 2

\subsection{CHANGE CONTROL}

Change control shall be managed in accordance with the MCO Project Management P1 an (PMP), WHC-SD-W442-PMP-001, Rev. 0. The Seller shall track changes less than $\$ 50,000$ and will be requested to maintain a log of all changes until the cumulative exceeds $\$ 50,000$. Once the cumulative total of Seller changes exceeds the $\$ 50,000$ threshold, the Seller shall submit a change request for approval.

\subsection{DESCRIPTION OF REQUIRED SERVICES}

The Seller is the fully responsible design agent for translating the MCO Subproject performance specification into a cost-effective final design. The tasks described in this section are those that the SNF MCO Subproject has specifically identified for the development of Phase 2 Design. The Seller may supplement this task 1 ist by adding new work items or upgrading definitions of identified tasks, as necessary, to satisfy its assessment of the tasks required to produce an acceptable Design that meets all technical and quality requirements.

\subsection{Phase 2 Design Objectives}

The overall objective is to produce final design media suitable for MCO procurement activities.

The principal objectives of the Phase 2 Design are as follows:

- Provide a fabrication specification and fabrication drawings in compliance with the Performance Specification that can be used for fixed price competitive procurement of the MCOs.

- Document compliance with the Performance Specification requirements.

- Provide input to the MCO Topical Design Report

\subsection{DESIGN WORK ITEMS}

The Seller is required to perform the following SNF MCO Subproject activities, at a minimum.

1. Review the Performance Specification and preliminary information provided for the SNF MCO Subproject, and identify those items or areas that require further clarification.

2. Develop the prototype design into a final design and document compliance with Performance Specification requirements. 
a. Provide an update to the Fabrication Specification (WHC-S0453, Rev. 0) to reflect compliance with the Performance Specification and consistency with the Phase 2 Design drawings.

b. Provide a Phase 2 Design Report describing the MCO features, materials, components, quality characteristics, safety features, etc. Include a detailed matrix listing the specific design requirements included in the Performance Specification and indicating how the design has complied with each requirement.

c. Prepare, review, and approve an ASME code exception report to the Performance Specification where the levels of compliance are described, exceptions described, and levels of the exceptions justified against the Performance Specification MCO life cycle paths. Suitability of the lesser compliance levels will be compared to the active service interval in the MCO life cycle path.

3. As part of the development of the Phase 2 Design of the MCO, the Seller may perform additional (not routine design) special studies/tasks as required or directed by the Technical Representative to evaluate alternatives and document design recommendations. Such studies shall be documented in topical reports that contain technical findings, tradeoffs, developments, analys is performed, recommendations, etc. The reports shall be prepared in accordance with applicable QA requirements such that content may be used as design input. A standard format shall be developed by the Seller with concurrence from the Technical Representative for use in preparing study reports. A detailed outline, including alternatives to be evaluated, work statements, decision hold points, and cost and schedule of each study, in the standard format, shall be submitted for approval.

4. Perform required shielding analyses and issue a report that documents the design's compliance with specification requirements. To ensure that standardized, validated methods are followed for shielding calculations, the Technical Representative will review and concur with the Seller's shielding design code(s). In addition, the Technical Representative will review and concur with source terms, bases for assumptions, and modeling done in support of shielding design to ensure that codes and the principles of "as low as reasonably achievable" have been properly applied. Shielding calculations may be reviewed by the Technical Representative before the Seller uses the calculated values in the design.

5. As requested, consult with and advise the Technical Representative concerning any questions that may arise in connection with the Seller services described within the contract. Participate in special study tasks, technical services, discussions, and meetings required on an "as-needed" basis to support the SNF MCO design and development. Provide assistance with briefings and formal 
presentations, as requested. The estimated frequency of presentations is one per month. Assistance shall include generation of briefing material (narratives, cost data, and graphics), participation in portions of the briefing, and responding to actions (via agreement/commitment documentation and meeting minutes) for which the Seller is made responsible.

6. Provide support in the development of a Topical Design Report with a description of safety systems and components, human factors, and design criteria.

7. Provide support for other special need items, such as independent engineering reviews, audits and surveillances, and independent cost estimate reviews, as required.

8. Supervise preparation of design, analyses, specifications, reports, and other items such that the fabrication drawings, fabrication specification, and exception report are approved per Section 3.5.4 of this SOW.

9. Prepare a packaging, shipping, and warehouse plan for MCOs and components as fabricated and shipped to the Hanford site for use. The plan shall address the following, at a minimum:

a. Identify potential locations for warehousing of MCOs and components on site.

b. Define package sizing

c. Identify required coverings/packaging suitable for warehouse environments.

d. Establish a numbering control methodology

e. Specify standard packaging identification

f. Identify cleaniness control requirements

Coordination and input from the WHC Material Control and Warehouse personnel on site will be required in order to prepare this plan. Packaging and shipping requirements developed in preparation of this plan shall be reflected in the fabrication specification.

11. Identify and provide design drawings for any special tools and/or handling devices for closing the MCO or movement of the MCOS and components during storage. This includes a means of 1 ifting an empty $M C O$ into the transportation cask at the CSB, but excludes grapples for handling the loaded MCO, loading baskets into the $\mathrm{MCO}$, and placing the shield plug into the MCO. 


\subsubsection{Design End Items}

Table 4-1 shows deliverable design end items for the Phase 2 design. The table also identifies responsibilities, approval levels, and schedule information. P=Prepare, $A=$ Approve, R=Review

Table 4-1 Design End Items

\begin{tabular}{|c|c|c|c|}
\hline \multicolumn{4}{|c|}{ Phase 1 Design Activities } \\
\hline Item & Seller & DESH & Schedule \\
\hline $\begin{array}{l}\text { Update to Phase } 1 \\
\text { Configuration } \\
\text { Management Plan }\end{array}$ & $P$ & $R / A$ & $\begin{array}{l}\text { within } 10 \\
\text { working days } \\
\text { ANTP }\end{array}$ \\
\hline $\begin{array}{l}\text { Monthly Reports, action } \\
\text { tracking, weekly } \\
\text { meetings }\end{array}$ & $P$ & $\mathrm{R}$ & $\begin{array}{l}\text { 10th of each } \\
\text { month ANTP }\end{array}$ \\
\hline $\begin{array}{l}\text { Update to Phase } 1 \\
\text { Quality Assurance Plan }\end{array}$ & $P$ & $R / A$ & $\begin{array}{l}\text { Within } 10 \\
\text { calendar } \\
\text { days ANTP }\end{array}$ \\
\hline $\begin{array}{l}\text { Fabrication } \\
\text { Specification }\end{array}$ & $P$ & $R / A$ & $\begin{array}{l}\text { At } \\
\text { identified } \\
\text { reviews }\end{array}$ \\
\hline $\begin{array}{l}\text { Phase } 2 \text { Fabrication } \\
\text { Drawings }\end{array}$ & $P$ & $R / A$ & $\begin{array}{l}\text { At } \\
\text { identified } \\
\text { reviews }\end{array}$ \\
\hline $\begin{array}{l}\text { Shielding Analyses } \\
\text { Report }\end{array}$ & $P$ & $R / A$ & $\begin{array}{l}\text { with } 90 \% \\
\text { review } \\
\text { package }\end{array}$ \\
\hline $\begin{array}{l}\text { Structural Design } \\
\text { Calculations }\end{array}$ & $P$ & $R / A$ & $\begin{array}{l}\text { with } 90 \% \\
\text { review } \\
\text { package }\end{array}$ \\
\hline Phase 2 Design Report & $P$ & $R / A$ & $\begin{array}{l}\text { At } \\
\text { identified } \\
\text { reviews }\end{array}$ \\
\hline $\begin{array}{l}\text { Packaging, Shipping, } \\
\text { and Warehouse Plan }\end{array}$ & $P$ & $R / A$ & $\begin{array}{l}\text { with } 90 \% \\
\text { review } \\
\text { package }\end{array}$ \\
\hline $\begin{array}{l}\text { ASME Code Exception } \\
\text { Report }\end{array}$ & $P$ & $R / A$ & $\begin{array}{l}\text { At } \\
\text { identified } \\
\text { reviews }\end{array}$ \\
\hline Special studies & $P$ & $\mathrm{R} / \mathrm{A}$ & as scheduled \\
\hline
\end{tabular}


HNF-SD-SNF-SOW-001

Rev. 2

\subsection{REFERENCES}

10 CFR 71, Subpart H, "Quality Assurance," Code of Federal Regulations, as amended.

ANSI/ASME, 1989, Quality Assurance Program Requirements for Nuclear Facilities, ANSI/ASME NQA-1-1989, American National Standards Institute/ American Society of Mechanical Engineers, New York, New York.

D0E, 1985, Uniform Reporting System, D0E Order 1332.1A, U.S. Department of Energy, Washington, D.C.

D0E, 1987, Project Management System, DOE Order 4700.1, U.S. Department of Energy, Washington, D.C.

D0E, 1988b, Records Disposition, D0E Order 1324.2A, U.S. Department of Energy, Washington, D.C.

DOE-RL, 1990, "Preparation and Control of Engineering and Fabrication Drawings," HPS-SDC-1.3, Rev. 6, Hanford Plant Standards, U.S. Department of Energy-Richland Operations Office, Richland, Washington.

HNF, 1996, "Performance Specification for Multi-Canister Overpack," HNF-S0426, Rev. 3, Duke Engineering \& Services Hanford, Richland, Washington

WHC, 1996, "Project W-442 Multi-Canister Overpack Project Management Plan," WHC-SD-W442-PMP-001, Rev. 0, Westinghouse Hanford Company, Richland, Washington 


\subsection{BIBLIOGRAPHY}

Clean Air Act of 1977, 42 USC 7401, et seq.

DOE, 1993, Extension of DOE N 4700.5, DOE N 4700.6, U.S. Department of Energy, Washington, D.C.

National Environmental Policy Act of 1969, 42 USC 4321 , et seq.

Resource Conservation and Recovery Act of 1976, 42 USC 6901, et seq.

RL, 1994, Project Cost Estimating, Analysis, and Cost Standardization, DOE RLID 5700.3, U.S. Department of Energy, Richland Operations Office, Richland, Washington. 


\subsection{ACRONYMS}

\section{ABBREVIATIONS AND ACRONYMS}

$\begin{array}{ll}\text { ANTP } & \text { after Notice to Proceed } \\ \text { AWP } & \text { in accordance with approved work plan } \\ \text { CADD } & \text { computer-aided design and drafting } \\ \text { CMP } & \text { Configuration Management Plan } \\ \text { CSB } & \text { Canister Storage Building } \\ \text { DESH } & \text { DE\&S Hanford, Inc. } \\ \text { DOE } & \text { U.S. Department of Energy } \\ \text { F\&R } & \text { Function and Requirements } \\ \text { LLW } & \text { low-level waste } \\ \text { MCO } & \text { multi-canister overpack } \\ \text { NRC } & \text { U.S. Nuclear Regulatory Commission } \\ \text { PMB } & \text { performance measurement baseline } \\ \text { PMP } & \text { Project Management Plan } \\ \text { PSEMP } & \text { Project Systems Engineering Management Plan } \\ \text { QAP } & \text { Quality Assurance Plan } \\ \text { RL } & \text { U.S. Department of Energy, Rich1and 0perations Office } \\ \text { ROM } & \text { rough-order-of-magnitude } \\ \text { SNF } & \text { spent nuclear fue1 } \\ \text { SOW } & \text { Statement of Work }\end{array}$




\section{DISTRIBUTION SHEET}

\begin{tabular}{|c|c|c|c|c|c|}
\hline \multirow{2}{*}{$\begin{array}{l}\text { To } \\
\text { Distribution }\end{array}$} & \multirow{2}{*}{\multicolumn{3}{|c|}{$\begin{array}{l}\text { From } \\
\text { MCO Subproject }\end{array}$}} & \multicolumn{2}{|l|}{ Page 1 of 1} \\
\hline & & & & \multicolumn{2}{|c|}{ Date $02 / 27 / 97$} \\
\hline \multicolumn{4}{|l|}{ Project Title/Work Order } & \multicolumn{2}{|l|}{ EDT No. $\mathrm{N} / \mathrm{A}$} \\
\hline \multicolumn{4}{|c|}{$\begin{array}{l}\text { Statement of Work for System Design and Engineering of the Spent } \\
\text { Nuclear Fuel Multi-Canister Overpack }\end{array}$} & \multicolumn{2}{|c|}{$\begin{array}{c}\text { ECN No. 6 } 638912 \\
\text { Kes } 3 / 3 / 97\end{array}$} \\
\hline Name & MSIN & $\begin{array}{c}\text { Text } \\
\text { With All } \\
\text { Attach. }\end{array}$ & Text Only & $\begin{array}{l}\text { Attach./ } \\
\text { Appendix } \\
\text { Only }\end{array}$ & $\begin{array}{c}\text { EDT/ECN } \\
\text { Only }\end{array}$ \\
\hline
\end{tabular}

W. C. Alaconis

P. D. Braun

J. I. Dieh1

J. R. Frederickson

L. J. Garvin

L. H. Goldmann

C. B. Loftis

B. D. Lorenz

D. W. McNally

R. W. Rasmussen

E. S. Ruff

K. E. Smith

SNF Project Files

MCO Project File 2.10
R3-85

G1-25

$\times 3-80$

R3-86

R3-15

R3-86

S7-41

R3-11

G1-12

R3-86

H5-70

R3-86

R3-11

R3-86 $x$
$x$
$x$
$x$
$x$
$x$
$x$
$x$
$x$
$x$
$x$
$x$
$x$
$x$ 